\title{
28 Research Square \\ The Current Status of Health Promotion Lifestyle and Its Related Factors in Chinese Residents
}

\author{
Qianqian Liu \\ Shandong University \\ Shusheng Huang \\ Shandong University \\ Xiaoyuan Qu \\ Henan University \\ Aitian Yin ( $\nabla$ yaitian@sdu.edu.cn ) \\ Shandong University
}

\section{Research Article}

Keywords: health attitude, health promotion lifestyle, health promotion, cross-sectional study

Posted Date: January 27th, 2021

DOl: https://doi.org/10.21203/rs.3.rs-149024/v1

License: (a) (i) This work is licensed under a Creative Commons Attribution 4.0 International License. Read Full License 


\section{Abstract}

Objectives: This study aimed to explore the current status of Chinese residents' health promotion lifestyle and its influencing factors, especially explore how health attitudes affect health promotion lifestyle, thus can make targeted recommendations for health promotion in China and similar areas.

Study design: This study was based on a household survey of 1769 adults aged 18 and over from Shandong Province of China conducted in 2018.

Methods: A cross-sectional, face-to-face survey design was used. The between-group measured data were compared by One-way ANOVA or $t$-tests. The correlation between the health attitude and health promotion lifestyle was examined by Pearson correlation. Logistic regression model was used to examine the related factors influencing Chinese residents' health promotion lifestyle.

Results: The health promotion lifestyle of residents in Chinese residents was not good. Significant differences existed in health promotion lifestyle among different genders, education levels, income levels, marital status, and health attitude $(P s<0.001)$. Multivariable Logistic regression model found that gender, education level, annual family per capita income, affection and behavioral intention in health attitude were key factors influencing Chinese residents' health promotion lifestyle $(P s<0.001)$.

Conclusions: Individual health responsibilities need to be further strengthened. More affective factors and operable measures should be added to enhance health affection and health behavioral intention, so as to enhance health promotion lifestyle.

\section{Introduction}

Several studies have demonstrated that lifestyle play a vital role in explaining health and disease, especially concerning the onset of disease, seeking help, disease management, and health outcomes [1-3]. Recent research revealed that the two biggest killers of human health are cigarette smoking and physical inactivity, accounting for more than 800,000 premature deaths in the United States annually, also exerting enormous adverse economic impact [4]. Poor lifestyle is the pathogenic factors constituting $70 \%$ of the top ten causes of diseases in the United States, while in China, the corresponding figure is $44.7 \%$ [5]. Thus, by examining the health promotion lifestyle of Chinese residents, the characteristics of residents' health promotion lifestyle in different groups can be identified to formulate a series of intervention measures to enhance the residents' health behaviors.

A majority of research suggests a significant link between attitude and health promotion lifestyle [6, 7]. According to several leading behavioral change frameworks including knowledge belief and attitude practice (KAP) [8], the theory of planned behavior (TPB) $[9,10]$, health attitude can affect their health promotion lifestyle to a certain extent, thereby affecting their health. An influential theory is that the structure of attitude includes three components-cognition, affection, and behavioral intention [11-13]. But many studies only focused on the cognitive aspects of health attitude. This study used 1769 adults aged 18 and over to explore the current status of Chinese residents' health promotion lifestyle and its influencing 
factors, especially explore how health attitude affect health promotion lifestyle. Relevant suggestions will be proposed to promote residents of China and similar areas to form health promotion lifestyle.

\section{Methods}

\section{Sample Group}

We selected residents of Shandong Province as investigation samples in this study. Shandong is an economically developed province of China, ranking third in China's GDP in 2018 [14]. Shandong Province has put great emphasis on residents' medical concern for several years, and has established a basic medical care system [15]. Furthermore, the economic status and employment category of residents can represent the status of the majority of Chinese residents.

We used a multistage stratified, cluster random sampling method to select the study population of the area. Based on the level of socioeconomic development, Jiaonan, Qufu, and Ningyang of Shandong Province were selected as sample counties. Based on the level of economic development, one street, one town, and three villages in each city/county were selected randomly for research. 600 people were selected from each city/county, adding up to 1800 people in total. A survey was conducted in community health centers or township health centers from March to May, 2018. Before the survey, the investigators had been trained to conduct preliminary publicity and introduction. The survey was conducted anonymously, and household cleaning products worth approximately 20CNY were provided to the participants as a reward after the survey. The study was conducted and approved by Ethics Committee of Centre for Health Management and Policy Research, School of Public Health, Cheeloo College of Medicine, Shandong University, and all the participants had given their informed consent. The study was conducted according to the guidelines of the Declaration of Helsinki.

\section{Data Collection Tools}

\section{Basic Sociodemographic Characteristics}

The questionnaire mainly involves gender, age, annual family per capita income, marital status, residence, education level, whether suffering from chronic diseases, and medical insurance status.

\section{Health Promotion Lifestyle Profile}

We used the Chinese version of the Health Promotion Lifestyle Profile (HPLP-IICR) [16]. The original version of the HPLP was developed by Walker et al. [17, 18], contains 52 items. The Chinese version of the HPLPIICR has been simplified by Deng and Yen [16], which contains 30 items, and five subscales, including Spiritual Growth (6 items), Physical Activity (6 items), Health Management (9 items), Nutrition (5 items), and Health Responsibility (4 items). A higher score indicates greater health promotion, using a 4-point Likert scale with choices ranging from never $=1$ to always $=4$. The overall Cronbach's alpha is 0.90 , with 0.69 to 0.87 for the subscales [16]. In the present study, the expression mode of some items has been 
adjusted to make it easy to be understood. Adjusted Cronbach's alpha for the total profile is 0.88 , with subscales ranging from 0.71 to 0.85 . The total score ranges between $30-120$, in which $30-52$ represents poor, 53-75 represents average, 76-98 represents good, and 99-120 represents excellent.

\section{Health Attitude Questionnaire}

A self-designed Health Attitude Questionnaire was used in the study, which using a 5-point Likert scale with choices ranging from totally disagree $=0$ to totally agree $=4[19,20]$. The original questionnaire was designed according to health promotion lifestyle, contained 30 items. The final questionnaire contains 23 items and, the Cronbach's a is 0.81 . We extracted three factors-Health Cognition ( 8 items), Health Affection (8 items), and Health Behavioral Tendency ( 7 items), which respectively explained $12.71 \%$, $15.37 \%$, and $23.80 \%$ of the total variance. The confirmatory factor analysis of the three-factor model resulted in an acceptable model fit (Tucker-Lewis Index $=0.90$, Comparative Fit Index $=0.92$, Normed Fit Index $=0.93$, Expected Cross-Validation Index $=0.35$, Root-Mean-Square Error of Approximation $=0.068$ ). The item loadings range from 0.72 to 0.83 , and correlation coefficients among the three factors range from 0.54 to 0.70 . The total score is between $0-92$, in which $0-30$ represents poor, $31-61$ represents average, and 62-92 represents good.

\section{Data Analysis}

In this study, the database was built using Access 2010 software; the data was recorded two times and compared to ensure data integrity and accuracy. The statistical analysis was performed using the Statistical Package for the Social Sciences version 24.0 (SPSS, Inc., Chicago, IL, USA). The independent variables of this study are individual-level factors (e.g., gender, age, education level, and so on.), which were summarized using descriptive statistics. The statistical description of the measurement data was expressed by mean and standard deviation (SD). Besides, the analysis of variance or $t$-test was used to compare the between-group measured data. All tests were bilateral, and the test level was set at $a=0.05$. The Pearson correlation coefficient was used to analyze the correlation between the health attitude and health promotion lifestyle. Multivariate logistic regression model was used to explore the related factors affecting Chinese residents' health promotion lifestyle. The results were exhibited as adjusted odds ratios (ORs) with their $95 \%$ confidence intervals (Cls).

\section{Results}

\section{Basic Sociodemographic Characteristics}

In this study, 1800 questionnaires were distributed, of which 1784 were collected, with 1769 valid responses (effective rate, 98.28\%). Among the 1769 respondents, $790(44.66 \%)$ are male and $979(55.34 \%)$ are female; the mean age is $45.6(\mathrm{SD}=9.12)$. Table 1 presents the sociodemographic data of study participants. 
Table 1

Characteristics of study participants $(n=1769)$

\begin{tabular}{|c|c|c|c|}
\hline Characteristics & $N(\%)$ & Characteristics & $N(\%)$ \\
\hline Age & & Education level & \\
\hline$<30$ & $133(7.5)$ & University and above & $598(33.8)$ \\
\hline $30-50$ & $\begin{array}{l}1243 \\
(70.3)\end{array}$ & High school & $724(40.9)$ \\
\hline$>50$ & $\begin{array}{l}393 \\
(22.2)\end{array}$ & Junior middle school and below & $447(25.3)$ \\
\hline $\begin{array}{l}\text { Annual family per capita income } \\
\text { (CNY) }\end{array}$ & & Marital status & \\
\hline$<10,000$ & $\begin{array}{l}506(28 . \\
6)\end{array}$ & Married & $\begin{array}{l}1396 \\
(78.9)\end{array}$ \\
\hline $10,000-20,000$ & $\begin{array}{l}587(33 . \\
2)\end{array}$ & Unmarried/Divorced & $182(10.3)$ \\
\hline$>20,000$ & $\begin{array}{l}676 \\
(38.2)\end{array}$ & Widowed & $191(10.8)$ \\
\hline Chronic disease & & Medical insurance & \\
\hline No & $\begin{array}{l}957 \\
(54.1)\end{array}$ & $\begin{array}{l}\text { Urban and Rural Basic Medical } \\
\text { Insurance }\end{array}$ & $\begin{array}{l}1244 \\
(70.3)\end{array}$ \\
\hline \multirow[t]{2}{*}{ Yes } & $\begin{array}{l}812 \\
(45.9)\end{array}$ & Urban Employee Medical Insurance & $506(28.6)$ \\
\hline & & Uninsured & $19(1.1)$ \\
\hline
\end{tabular}

\section{Status of Health Promotion Lifestyle}

The mean (SD) of HPLP-IICR total score of 1769 was 82.12(16.63). In 1769 residents, 254scored poor, accounting for $14.36 \% ; 710$ scored average, accounting for $40.14 \%$; 612 scored good, accounting for $34.60 \%$; 193 scored excellent, accounting for $10.91 \%$. After standardized calculation, the mean (SD) of items was 2.73(0.78), 3.08 (0.74) for Nutrition 2.97 (0.79) for Physical Activity, 2.85 (0.78) for Health Management, 2.60 (0.88) for Spiritual Growth, and 2.42 (0.89) for Health Responsibility. As shown in Table 2, one-way ANOVA and $t$-test were used to compare differences in health promotion lifestyle among residents with different characteristics. The residents' health promotion lifestyle was significantly different $(P s<0.001)$ among different genders, education levels, annual family per capita income, marital status, and health attitude. 
Table 2

One-way ANOVA or t-test of different sociodemographic factors on health promotion lifestyle and attitude in Chinese residents

\begin{tabular}{|c|c|c|c|c|c|c|}
\hline Predictor & $\begin{array}{l}\text { Spiritual } \\
\text { growth } \\
\text { Mean } \pm \\
\text { SD }\end{array}$ & $\begin{array}{l}\text { Physical } \\
\text { activity } \\
\text { Mean } \pm \\
\text { SD }\end{array}$ & $\begin{array}{l}\text { Health } \\
\text { management } \\
\text { Mean } \pm \text { SD }\end{array}$ & $\begin{array}{l}\text { Nutrition } \\
\text { Mean } \pm \\
\text { SD }\end{array}$ & $\begin{array}{l}\text { Health } \\
\text { responsibility } \\
\text { Mean } \pm \text { SD }\end{array}$ & 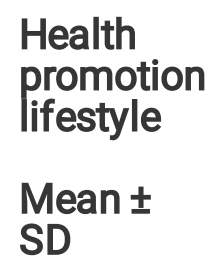 \\
\hline \multicolumn{7}{|l|}{ Gender } \\
\hline Male & $\begin{array}{l}2.58 \pm \\
0.53\end{array}$ & $\begin{array}{l}2.86 \pm \\
0.85\end{array}$ & $2.76 \pm 0.98$ & $\begin{array}{l}3.12 \pm \\
0.54\end{array}$ & $2.28 \pm 0.68$ & $\begin{array}{l}78.22 \pm \\
19.56\end{array}$ \\
\hline Female & $\begin{array}{l}2.71 \pm \\
0.93\end{array}$ & $\begin{array}{l}3.04 \\
\pm 0.74\end{array}$ & $2.93 \pm 0.93$ & $\begin{array}{l}3.09 \pm \\
0.44\end{array}$ & $2.47 \pm 0.94$ & $\begin{array}{l}86.12 \\
\pm 14.32\end{array}$ \\
\hline$P$ & $<0.001$ & $<0.001$ & $<0.001$ & 0.482 & $<0.001$ & $<0.001$ \\
\hline \multicolumn{7}{|l|}{ Age } \\
\hline$<30$ & $\begin{array}{l}2.89 \pm \\
0.87\end{array}$ & $\begin{array}{l}3.01 \pm 0 . \\
61\end{array}$ & $2.88 \pm 0.72$ & $\begin{array}{l}3.04 \pm \\
0.98\end{array}$ & $2.38 \pm 0.88$ & $\begin{array}{l}83.76 \pm \\
15.07\end{array}$ \\
\hline $30-55$ & $\begin{array}{l}2.56 \pm \\
0.63\end{array}$ & $\begin{array}{l}2.57 \pm \\
0.43\end{array}$ & $2.84 \pm 0.75$ & $\begin{array}{l}3.01 \pm \\
0.53\end{array}$ & $2.47 \pm 0.77$ & $\begin{array}{l}82.72 \pm \\
14.41\end{array}$ \\
\hline$>55$ & $\begin{array}{l}2.78 \\
\pm 0.56\end{array}$ & $\begin{array}{l}2.98 \pm \\
0.94\end{array}$ & $2.79 \pm 0.71$ & $\begin{array}{l}3.22 \pm \\
0.81\end{array}$ & $2.41 \pm 0.56$ & $\begin{array}{l}82.89 \pm \\
13.91\end{array}$ \\
\hline$P$ & $<0.001$ & $<0.001$ & 0.341 & $<0.001$ & 0.071 & 0.122 \\
\hline \multicolumn{7}{|l|}{ Residence } \\
\hline Rural & $\begin{array}{l}2.41 \pm \\
0.88\end{array}$ & $\begin{array}{l}2.99 \pm \\
0.97\end{array}$ & $2.92 \pm 0.91$ & $\begin{array}{l}3.04 \pm \\
0.91\end{array}$ & $2.39 \pm 0.75$ & $\begin{array}{l}82.05 \pm \\
14.02\end{array}$ \\
\hline Urban & $\begin{array}{l}2.76 \pm \\
0.85\end{array}$ & $\begin{array}{l}2.89 \pm \\
0.82\end{array}$ & $2.77 \pm 0.98$ & $\begin{array}{l}3.10 \pm \\
0.54\end{array}$ & $2.45 \pm 0.72$ & $\begin{array}{l}83.17 \pm \\
15.18\end{array}$ \\
\hline$P$ & $<0.001$ & 0.055 & $<0.001$ & 0.071 & 0.229 & 0.157 \\
\hline \multicolumn{7}{|l|}{ Education level } \\
\hline $\begin{array}{l}\text { Junior middle } \\
\text { school \& below }\end{array}$ & $\begin{array}{l}2.63 \pm \\
0.98\end{array}$ & $\begin{array}{l}2.67 \pm \\
0.53\end{array}$ & $2.58 \pm 0.90$ & $\begin{array}{l}2.82 \pm \\
0.74\end{array}$ & $2.40 \pm 0.79$ & $\begin{array}{l}80.92 \pm 1 \\
4.78\end{array}$ \\
\hline High school & $\begin{array}{l}2.58 \pm \\
0.97\end{array}$ & $\begin{array}{l}2.87 \pm \\
0.84\end{array}$ & $3.02 \pm 0.83$ & $\begin{array}{l}2.99 \pm \\
0.78\end{array}$ & $2.41 \pm 0.82$ & $\begin{array}{l}82.54 \pm 1 \\
3.78\end{array}$ \\
\hline University \& above & $\begin{array}{l}2.75 \pm \\
0.89\end{array}$ & $\begin{array}{l}2.97 \pm \\
0.87\end{array}$ & $2.79 \pm 0.93$ & $\begin{array}{l}3.12 \pm \\
0.85\end{array}$ & $2.46 \pm 0.85$ & $\begin{array}{l}85.16 \pm \\
16.85\end{array}$ \\
\hline$P$ & $<0.001$ & $<0.001$ & $<0.001$ & $<0.001$ & 0.331 & $<0.001$ \\
\hline
\end{tabular}




\begin{tabular}{|c|c|c|c|c|c|c|}
\hline Predictor & $\begin{array}{l}\text { Spiritual } \\
\text { growth } \\
\text { Mean } \pm \\
\text { SD }\end{array}$ & $\begin{array}{l}\text { Physical } \\
\text { activity } \\
\text { Mean } \pm \\
\text { SD }\end{array}$ & $\begin{array}{l}\text { Health } \\
\text { management } \\
\text { Mean } \pm \text { SD }\end{array}$ & $\begin{array}{l}\text { Nutrition } \\
\text { Mean } \pm \\
\text { SD }\end{array}$ & $\begin{array}{l}\text { Health } \\
\text { responsibility } \\
\text { Mean } \pm \text { SD }\end{array}$ & $\begin{array}{l}\text { Health } \\
\text { promotion } \\
\text { lifestyle } \\
\text { Mean } \pm \\
\text { SD }\end{array}$ \\
\hline$<10,000 \mathrm{RMB}$ & $\begin{array}{l}2.56 \\
\pm 0.97\end{array}$ & $\begin{array}{l}2.94 \\
\pm 0.88\end{array}$ & $2.76 \pm 0.83$ & $\begin{array}{l}2.91 \pm \\
2.01\end{array}$ & $2.14 \pm 2.78$ & $\begin{array}{l}80.95 \pm \\
14.78\end{array}$ \\
\hline $\begin{array}{l}10,000-20,000 \\
\text { RMB }\end{array}$ & $\begin{array}{l}2.60 \pm \\
0.92\end{array}$ & $\begin{array}{l}2.93 \pm \\
.0 .77\end{array}$ & $2.84 \pm 0.65$ & $\begin{array}{l}3.02 \pm \\
1.78\end{array}$ & $2.39 \pm 1.83$ & $\begin{array}{l}80.76 \pm 1 \\
3.94\end{array}$ \\
\hline$>20,000 \mathrm{RMB}$ & $\begin{array}{l}2.64 \pm \\
0.91\end{array}$ & $\begin{array}{l}3.13 \pm \\
0.93\end{array}$ & $2.95 \pm 0.77$ & $\begin{array}{l}3.16 \pm \\
2.22\end{array}$ & $3.52 \pm 2.18$ & $\begin{array}{l}87.01 \\
\pm 14.91\end{array}$ \\
\hline$P$ & 0.663 & $<0.001$ & $<0.001$ & $<0.001$ & $<0.001$ & $<0.001$ \\
\hline \multicolumn{7}{|l|}{ Marital status } \\
\hline Married & $\begin{array}{l}2.68 \\
\pm 0.82\end{array}$ & $\begin{array}{l}2.66 \pm \\
0.79\end{array}$ & $3.07 \pm 0.99$ & $\begin{array}{l}3.06 \pm \\
0.74\end{array}$ & $2.51 \pm 0.91$ & $\begin{array}{l}85.29 \pm \\
15.01\end{array}$ \\
\hline Unmarried/Divorced & $\begin{array}{l}2.60 \pm \\
0.98\end{array}$ & $\begin{array}{l}3.11 \pm \\
0.93\end{array}$ & $2.88 \pm 0.75$ & $\begin{array}{l}3.09 \pm \\
0.80\end{array}$ & $2.47 \pm 0.79$ & $\begin{array}{l}83.18 \pm \\
13.84\end{array}$ \\
\hline Widowed & $\begin{array}{l}2.46 \pm \\
0.90\end{array}$ & $\begin{array}{l}2.58 \pm \\
0.84\end{array}$ & $2.62 \pm 0.96$ & $\begin{array}{l}2.91 \pm \\
0.77\end{array}$ & $2.36 \pm 0.64$ & $\begin{array}{l}80.96 \pm \\
13.10\end{array}$ \\
\hline$P$ & $<0.001$ & $<0.001$ & $<0.001$ & 0.056 & $<0.001$ & $<0.001$ \\
\hline \multicolumn{7}{|l|}{ Chronic diseases } \\
\hline No & $\begin{array}{l}2.72 \\
\pm 0.86\end{array}$ & $\begin{array}{l}2.95 \pm \\
0.68\end{array}$ & $2.56 \pm 0.80$ & $\begin{array}{l}3.06 \\
\pm 0.73\end{array}$ & $2.36 \pm 2.96$ & $\begin{array}{l}81.90 \pm 1 \\
5.16\end{array}$ \\
\hline Yes & $\begin{array}{l}2.55 \pm \\
0.75\end{array}$ & $\begin{array}{l}2.98 \pm \\
0.92\end{array}$ & $2.98 \pm 0.78$ & $\begin{array}{l}3.11 \pm \\
0.85\end{array}$ & $2.58 \pm 2.29$ & $\begin{array}{l}82.89 \pm 1 \\
4.03\end{array}$ \\
\hline$P$ & $<0.001$ & 0.696 & $<0.001$ & 0.779 & $<0.001$ & 0.364 \\
\hline \multicolumn{7}{|l|}{ Health attitude } \\
\hline Poor & $\begin{array}{l}2.52 \pm \\
0.61\end{array}$ & $\begin{array}{l}2.92 \pm \\
0.98\end{array}$ & $2.75 \pm 0.72$ & $\begin{array}{l}3.03 \pm \\
0.66\end{array}$ & $2.16 \pm 0.44$ & $\begin{array}{l}80.98 \pm \\
15.25\end{array}$ \\
\hline Average & $\begin{array}{l}2 . .68 \pm \\
0.79\end{array}$ & $\begin{array}{l}2.98 \pm \\
0.88\end{array}$ & $2.78 \pm 0.82$ & $\begin{array}{l}3.06 \pm \\
0.88\end{array}$ & $2.44 \pm 0.79$ & $\begin{array}{l}81.77 \pm \\
16.77\end{array}$ \\
\hline Good & $\begin{array}{l}2.82 \pm \\
0.75\end{array}$ & $\begin{array}{l}3.05 \pm \\
0.71\end{array}$ & $2.98 \pm 0.88$ & $\begin{array}{l}3.10 \\
\pm 0.75\end{array}$ & $2.62 \pm 0.77$ & $\begin{array}{l}86.44 \pm 1 \\
4.13\end{array}$ \\
\hline$P$ & $<0.001$ & $<0.001$ & $<0.001$ & 0.083 & $<0.001$ & $<0.001$ \\
\hline
\end{tabular}

\section{Correlation Analysis of Health Attitude and Health Promotion Lifestyle}


As shown in Table 3, the three aspects of health attitude are correlated with multiple aspects of health promotion lifestyle, suggesting that health attitude is a significant predictor of health promotion lifestyle.

Table 3

Correlation analysis of health attitude and health promotion lifestyle

\begin{tabular}{|lllllll|}
\hline Predictor & $\begin{array}{l}\text { Spiritual } \\
\text { growth }\end{array}$ & $\begin{array}{l}\text { Physical } \\
\text { activity }\end{array}$ & $\begin{array}{l}\text { Health } \\
\text { management }\end{array}$ & Nutrition & $\begin{array}{l}\text { Health } \\
\text { responsibility }\end{array}$ & $\begin{array}{l}\text { Health } \\
\text { promotion } \\
\text { lifestyle }\end{array}$ \\
\hline Cognition & 0.03 & $0.06 *$ & $0.07 *$ & $0.20 * *$ & 0.02 & $0.06 *$ \\
\hline Affection & 0.08 & $0.37 * *$ & $0.33 *$ & $0.10 *$ & $0.30 *$ & $0.38 * *$ \\
\hline $\begin{array}{l}\text { Behavioral } \\
\text { intention }\end{array}$ & $0.34 * *$ & $0.44 * *$ & $0.09 *$ & $0.41 * *$ & $0.12 * *$ & $0.33 * *$ \\
\hline $\begin{array}{l}\text { Health } \\
\text { attitude }\end{array}$ & 0.28 & $0.38 * *$ & $0.10 *$ & $0.36 * *$ & $0.34 *$ & $0.32 * *$ \\
\hline$* * P<0.01, * P<0.05$ & & & & & \\
\hline
\end{tabular}

\section{Logistic Regression Analysis of Relevant Factors Influencing Health Promotion Lifestyle}

With health promotion lifestyle ( 0 = excellent and good, $1=$ average and poor $)$ as the dependent variable, significant factors in single-factor analysis were selected as independent variables for multivariate logistic regression analysis, which include gender, education level, annual family per capita income, marital status, and three factors of health attitude: health cognition, health affection, and health behavioral intention. Results indicated that the independent factors influencing health promotion lifestyle include gender, education level, annual family per capita income, health affection, and health behavioral intention. As shown in Table 4, The findings suggested that male ( $\mathrm{OR}=0.25,95 \% \mathrm{Cl}: 0.12-0.34)$, high school education level $(\mathrm{OR}=0.20,95 \% \mathrm{Cl}: 0.17-0.41)$, junior middle school \& below $(\mathrm{OR}=0.29 ; 95 \% \mathrm{Cl}: 0.12-0.33)$, annual family per capita income with $<10,000 \mathrm{CNY}(\mathrm{OR}=2.53,95 \% \mathrm{Cl}: 1.24-3.06$; OR $=2.14,95 \% \mathrm{Cl}: 1.08-3.12)$, low health affection $(\mathrm{OR}=2.99,95 \% \mathrm{Cl}: 2.15-4.22)$, and low health behavioral intention $(\mathrm{OR}=3.21 ; 95 \% \mathrm{Cl}$ : 2.33-5.29) were statistically significant predictors of average or poor health promotion lifestyle. 
Table 4

Logistic regression analysis of relevant factors affecting health promotion lifestyle in Chinese residents

\begin{tabular}{|c|c|c|c|c|c|c|c|}
\hline \multirow[t]{2}{*}{ Variables } & \multirow{2}{*}{$\begin{array}{l}\text { Reference } \\
\text { group }\end{array}$} & \multirow[t]{2}{*}{ B } & \multirow[t]{2}{*}{ SE } & \multirow[t]{2}{*}{ Wald } & \multirow{2}{*}{\multicolumn{2}{|c|}{ OR }} & $95 \% \mathrm{Cl}$ \\
\hline & & & & & & & $\begin{array}{l}\text { Lower } \\
\text { limit }\end{array}$ \\
\hline
\end{tabular}

Gender

$\begin{array}{lllllllll}\text { Male } & \text { Female } & -1.397 & 0.295 & 36.61 & < & 0.35 & 0.12 & 0.34\end{array}$

Education level

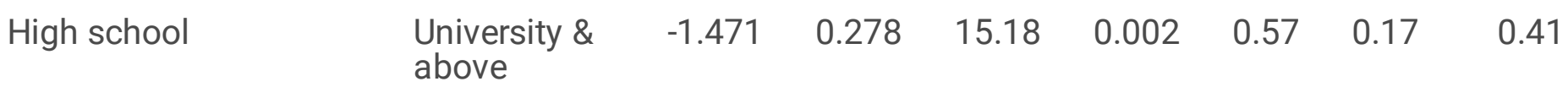

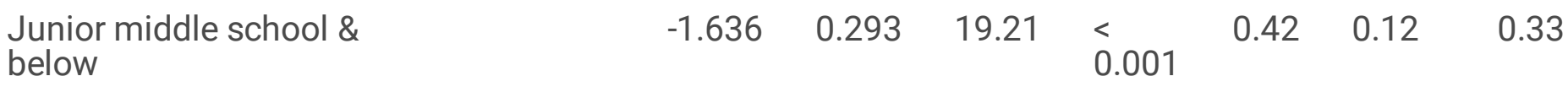

Annual family per

capita income

\begin{tabular}{lllllllll}
$>20,000 \mathrm{CNY}$ & $<10,000 \mathrm{CNY}$ & 1.324 & 0.264 & 10.25 & 0.002 & 2.53 & 1.24 & 2.06 \\
\hline $10,000-20,000 \mathrm{CNY}$ & & 0.928 & 0.377 & 11.83 & $<$ & 2.14 & 1.08 & 3.12
\end{tabular}

Health affection

$\begin{array}{lllllllll}\text { Low grouping } & \begin{array}{l}\text { High } \\ \text { grouping }\end{array} & -1.208 & 0.241 & 12.24 & 0.001 & 0.39 & 2.15 & 4.22\end{array}$

Health behavioral

intention

Low grouping

High
grouping

$-1.325 \quad 0.268$

13.15

$<.001$

$0.21 \quad 2.33$

5.29

\section{Discussion}

This study has confirmed that mean score for health promotion lifestyle reaches $(82.12 \pm 16.63)$, but $54.50 \%$ of the participants are in the status of average or poor, so the overall conditions of Chinese adults' health promotion lifestyle is not good. That is consistent with previous studies of Chinese [21, 22], and is lower than studies of Xia, Chen et al. [23, 24]. The score of Nutrition is the highest $(3.08 \pm 0.74)$, which is the same as the research results of Chen, Zhao and other scholars [22, 25]. With the increasing improvement of living standards and the popularization of nutrition knowledge, Chinese residents have higher requirements on diet, not only to satisfy their appetite, but also to pay more attention to nutrition ingredients and dietary collocation. The score of Physical Activity is the second highest (2.97 \pm 0.79$)$, which is different from previous studies $[23,24]$. The reason may be due to the differences between the scales used in this survey and those used in other surveys. After revision, the items that do not conform to Chinese culture had been deleted, so that they were easier to be understood [16]. It was worth noting that Chinese women showed 
better physical activity than men, which was different from studies of South Koreans [26] and Americans [27]. Perhaps this is because several Chinese women went square dancing as a way of exercise. Square dancing refers to dancing in an open and public space in China, usually on a flat patch such as a public square [28]. This group exercise has become popular in both urban and rural regions across China in recent 15 years [29,30] and has been popular, mainly among women [28]. Thanks to its convenience, low cost and social function, square dancing has enabled Chinese women to get physical activity and spiritual satisfaction after work and housework [31]. It is interesting to note that unlike previous studies [32] reporting that living with a partner exerts positive influence on physical activity, this study found that married people's Physical Activity is worse than that of unmarried people. That may be because in Chinese tradition, married people should take more family-oriented economic responsibilities and the responsibility of raising children, which makes them more inclined to spend their spare time and energy on work and raising children. The score of Health Responsibility got the lowest $(2.42 \pm 0.89)$, similar results had been reported by Zhang [33], whose study also based on residents of northern China. This may be due to the lack of emphasis on self-responsibility for health in northern Chinese culture.

A significant and novel work of this study is to discover whether health attitude can influence health promotion lifestyle. Our main finding is that three aspects of health attitude have certain influence on health behavior, among which health cognition has the least influence, followed by health affection, and health behavioral intention has the greatest influence. The influence of health cognition on health promotion lifestyle has been discussed in many previous studies [34]. This study has found that health affection plays a more important role in the initiation of health promotion lifestyle than health cognition, that was not presented in other studies. The impact of health behavior intention on health behavior has been confirmed by several studies [35], some of which focus on promoting health promotion lifestyle in people without health motivation [36]. However, based on this study, if people can have health related knowledge and health affective experience at the same time and further develop corresponding behavioral intention, it is more likely to have health promotion lifestyle.

In addition to attitude, this study found that female residents may adopt more health promotion lifestyle, corroborating several studies $[37,38]$. The effects of education and family income on health behavior are similar to previous studies [39,40]. Prior studies suggested that poorly educated adults may have difficulty in understanding medical statistics, drug dose requirements, and basic health concepts such as daily nutritional value [41-43]. People with a high school diploma or above, tend to seek and use health information, regardless of their educational level and other sociodemographic factors $[44,45]$.

In China, as in other countries, inconsistencies in health behavior due to differences in gender, wealth, and education still persist; thus, decreasing the gap should be a top issue of particular urgency to both public and private sectors [46]. Due to the important influence of health attitude on health promotion lifestyle, affection and behavioral intention should be fully considered in the process of health promotion. For example, health promotion programs should be designed with elements that evoke affection in the residents, health-relevant motor manipulations can facilitate health behavior change and higher intentionbehavior consistency [47]. Based on the characteristics of Chinese residents' greater emphasis on family responsibilities, more health promotion projects aimed at adolescents and requiring family participation 
could be designed. In order to compensate for the lack of health responsibility, while improving the accessibility and quality of health services, the propaganda of "everyone is the first person responsible for his/her own health" should be strengthened.

\section{Limitations}

The findings of this study should be considered in light of some limitations. Health attitudes and health promotion lifestyle are self-reported variables, so that report bias may exist. In the study, only Shandong Province residents have been conducted the survey, so that the representativeness may be limited. However, despite these limitations, this study can reflect the current health promotion lifestyle of Chinese residents and, reveal the influence of health attitude on health promotion lifestyle. It also provides relevant suggestions for the formulation of relevant health policies.

\section{Conclusions}

This study found that the general health promotion lifestyle in Chinese residents is not good. Of note, gender, education level, annual family per capita income, health affection, and health behavioral intention are significant factors influencing residents' health promotion lifestyle. Furthermore, this study suggests that more affective factors and operable measures should be added to enhance health affection and health behavioral intention. Individual health responsibilities should be emphasized and health promotion projects involving all family members should be designed, so as to enhance health promotion lifestyle.

\section{Abbreviations}

WHO: World Health Organization

HPLP: Health Promotion Lifestyle Profile

\section{Declarations}

\section{Acknowledgements}

The authors thank Guowen Wang, Chaofan Li, Tiecheng Liu, Panpan Dong, Xiufang Lu for field survey and data entry.

\section{Author Contributions}

Aitian Yin conceived and designed the research, and provided supervision and guidance to the writing of the article. Qianqian Liu designed the questionnaire. Qianqian Liu, Shusheng Huang extracted data, Qianqian Liu drafted the first version of the manuscript. Xiaoyuan Qu gave review suggestions on the 
entire writing process. Aitian Yin reviewed, edited and modified the manuscript critically for important intellectual content.

\section{Funding}

This article is based on research funded by the National Natural Science Foundation of China (71373147).

\section{Conflicts of Interest}

The authors declare no conflict of interest.

\section{Availability of data and materials}

The datasets used during the current study are available from the corresponding authors on reasonable request.

\section{Ethics approval and consent to participate}

The study was conducted and approved by Ethics Committee of Centre for Health Management and Policy Research, School of Public Health, Cheeloo College of Medicine, Shandong University, and all the participants had given their informed consent.

\section{Consent for publication}

Not applicable.

\section{Competing interests}

The authors declare that they have no competing interests.

\section{References}

1. Coreil, J.M. Social and behavioral foundations of public health. 2nd edition. SAGE Publications, 2009 Jan 21.

2. Redding, C.A.; Rossi, J.; Rossi, S.; Velicer, W. F.; Prochaska, J. O. Health behavior models. Int Electron J Health Educ. 2000, 3, 180-193. 
3. Greene, G.W.; Redding, C.A.; Prochaska, J.O.; Paiva, A. L.; Rossi, J. S.; Velicer, W. F.; Blissmer, B.; Robbins, M. L. Baseline transtheoretical and dietary behavioral predictors of dietary fat moderation over 12 and 24months. Eating Behaviors. 2013, 14, 255-262.

4. Borrel, L.N., Samuel, L. Body mass index categories and mortality risk in US adults: the effect of overweight and obesity on advancing death. Am. J. Public Health. 2014,104, 512-519.

5. Zhao, S.Y. Community Health Education and Health Promotion. Beijing: Peking University Medical Press. 2011.

6. Shrigley, R.L. Attitude and behavior are correlates. Journal of Research in Science Teaching. 1990, 27, 97-113.

7. Lutter, J.I., Szentes, B., Wacker, M.E., Winter, J.; Wichert, S.; Peters, A.; Holle, R.; Leidl, R. Are health risk attitude and general risk attitude associated with healthcare utilization, costs and working ability? Results from the German KORA FF4 cohort study. Health Econ Rev. 2019, 9.

8. Tiago, P. S.; William, M. L.; Carlos, A. S. T. S.; Maria, C. C. A.; Edson, D. M. J. Factors associated with the acceptance of the influenza vaccine among health workers: knowledge, attitude and practice. Ciencia \& saude coletiva, 2019, 24, 3147-3158.

9. Zhang, Z.; Zhu, Y.; Zhang, L.; Wan, H. What factors influence exclusive breastfeeding based on the theory of planned behaviour. Midwifery. 2018, 62, 177-182.

10. Ajzen, I. The theory of planned behaviour is alive and well, and not ready to retire: a commentary on Sniehotta, Presseau, and Araújo-Soares. Health Psychol Rev 2015, 9, 131-137.

11. Eagly, A.H.; Chaiken, S. The psychology of attitudes. Harcourt Brace Jovanovich College Publishers. 1993.

12. McGuire, W.J. Attitudes and attitude change. In: Gardner L, Aronson E, eds. Handbook of social psychology. New York: Random House, 1985, 233-246.

13. Nesdale, D.; Durkin, K. Stereotypes and attitudes: implicit and explicit processes. Mahwah, NJ: Lawrence Erlbaum. 1998, 219-232.

14. Li, X. Shandong's GDP was adjusted to 6.664.9 trillion yuan in 2018. https://baijiahao.baidu.com/s? $\mathrm{id}=1656343217664613226 \& \mathrm{wfr}=$ spider\&for=pc.

15. Liu Y. By 2020, Shandong will have completed a basic medical and health system covering both urban and rural residents. http://news.iqilu.com/shandong/yuanchuang/2018/0212/3837349.shtml

16. Teng, H.;Yen, M.; Susan, F. Health promotion lifestyle profile-Il: Chinese version short form. Journal of Advanced Nursing, 2010, 66, 1864-1873.

17. Walker, S.N.; Sechrist, K.R.; Pender, N.J. The Health-Promoting Lifestyle Profile: Development and psychometric characteristics. Nursing Research, 1987, 36, 76-81.

18. Pender, N.; Murdaugh, C.; Parsons, M.A. Health Promotion in Nursing Practice, (5th ed). Upper Saddle River, NJ, USA: Pearson Education, 2005.

19. Emrah, G.; Ömay, Ç.; Çilem, D.G. Development of an attitudes scale towards online assessment. Procedia-Social and Behavioral Sciences. 2015, 174, 529-536. 
20. Walker, M.; Heere, B. Consumer attitudes towards responsible entities in sport (CARES): scale development and model testing. Sport Management Review. 2011, 14, 153-166.

21. Xia, X.; Chen, C.; Hu, L.; Xie, J.; Wang, Z. Health-promoting lifestyle and influencing factors of wrinkly and elderly residents, Sichuan. Modern Preventive Medicine, 2019, 46, 3575-3579.

22. Chen, Z.; Dai, Y. Status of Health囚promoting Lifestyle of the Community Elderly in Taijiang District of Fuzhou City and Its Influencing Factors. Medicine and Society. 2020, 33, 50-54.

23. Wang, Y.; Li, F.; Chen, Y.; Bian, S.; Yang, L. Investigation on health-promoting lifestyles among people receiving health examination in Shenzhen. Chin J Nurs Educ, 2010, 7, 557-559.

24. Hu, Y.; Tao, L. Investigation of State Quo of Health囚Promoting Lifestyle Among Elderly in Nanjing Communities. Medicine and Society, 2017, 30, 77-80.

25. Zhao, J.; Tang, W. Study on health-promoting lifestyle and influential factors of the aged in Chengdu. Modern Preventive Medicine, 2018, 45, 663-665.

26. Kim, SC. Health Behaviors: A Cross-Sectional Study of South Korean Residents in a Metropolitan Area. Med Clin Rev, 2018, 4, 1.

27. Schoenborn, C.A., Adams, P.F.; Peregoy, J.A. Health behaviors of adults: united states, 2008-2010. 2013.

28. Zhang, Q.; Min. G. Square dancing: A multimodal analysis of the discourse in the People's Daily. Chinese Language and Discourse, 2019, 10, 61-83.

29. Maggie Chao. Global to Village Reading Movement in the Everyday: The Rise of Guangchangwu in a Chinese Village. International Journal of Communication. 2017, 11, 4499-4522.

30. Huang. A. Analysis of Design Principles and Elements of Square Fitness Dance. Proceeding of the 4th International Conference on Literature, Linguistics and Arts. UK: Francis Academic Press. 2017, 59-62.

31. Yu, C.; Rau, P. L. P. Studying the acceptance of somatosensory game for chinese square dancers. Procedia Manufacturing. 2015, 3, 2213-2218.

32. Schone, B.S.; Weinick, R.M. Health-related behaviors and the benefits of marriage for elderly persons. Gerontologist. 1998, 38, 618-627.

33. Zhang, S.; Tao, F.; Atsushi, U.; Wei, C.; Fang, J. The influence of health-promoting lifestyles on the quality of life of retired workers in a medium-sized city of Northeastern China. Environmental Health \& Preventive Medicine. 2013, 18, 458-465.

34. Perry, C. L.; Baranowski, T.; Parcel, G. S. How individuals, environments, and health behavior interact: Social learning theory. Health Education \& Behavior, 1990, 161-186.

35. Schwarzer, R. Self-efficacy in the adoption and maintenance of health behaviours: theoretical approaches and a new model, in Self-Efficacy: Thought control of Action. Schwarzer R, Editor. Hemisphere: Washington DC. 1992, 217-242.

36. Hardcastle, S. J.; Jennie, H.; Anne, H.; Chloe, M. S.; Cecilie, T. N.; Hagger, M. S. Motivating the unmotivated: how can health behavior be changed in those unwilling to change?. Frontiers in Psychology. 2015, 16, 835. 
37. Kim, H.; Kwon, S.; Kim, H.; Park, Y.; Koh, C. Health-promoting lifestyle behaviors and psychological status among Arabs and Koreans in the United Arab Emirates. Research in nursing \& health. 2015,38, 133-141.

38. Ozvurmaz, S.; Mandıracıoglu, Aliye. Healthy lifestyle behavior of employees in small and mediumsized enterprises in Aydin, Turkey. Pak J Med Sci. 2017, 33, 404-410.

39. Nandi, A.; Glymour, M. M.; Subramanian, S. V. Association among socioeconomic status, health behaviors, and all-cause mortality in the united states. Epidemiology. 2014, 25, 170-177.

40. Barros, M. B. D. A.; Margareth Guimarães Lima.; Medina, L. D. P. B. Szwarcwald, C. L.; Malta, D. C. Social inequalities in health behaviors among Brazilian adults: national health survey, 2013. International Journal for Equity in Health. 2016, 15, 1.

41. Rothman, R.L.; Housam R.; Weiss, H.; Davis, D.; Gregory, R.; Gebretsadik, T. et al. Patient understanding of food labels: the role of literacy and numeracy. Am J Prev Med. 2006, 31, 391-398.

42. Bostock, S.; Steptoe, A. Association between low functional health literacy and mortality in older adults: longitudinal cohort study. BMJ. 2012, 344, e1602.

43. Dutta-Bergman. Mohan, J. Primary sources of health information: comparisons in the domain of health attitudes, health cognitions, and health behaviors. Health Commun. 2004, 16, 273-288.

44. OECD. OECD Skills Outlook 2013: first results from the survey of adult skills. Oecd. 2013.

45. Egerter, S.; Braveman, P.; Sadegh-Nobari T.; Grossman-Kahn R.; Dekker M. Education matters for health. Issue Brief 6: education and health. Princeton, NJ: Robert Wood Johnson Foundation. 2009.

46. Iris, F.; Jan, F.; Vicki, J. L.; Daphne, G.; Elena, N.; Chelsea, M.; Hajo, Z. Examining Associations between Health Information Seeking Behavior and Adult Education Status in the U.S.: An Analysis of the 2012 PIAAC Data. Plos One. 2016, 11, e0148751.

47. Sherman, D.K.; Gangi, C.; White, M.L. Embodied cognition and health persuasion: facilitating intentionbehavior consistency via motor manipulations. Journal of Experimental Social Psychology. 2010, 46, 461-464. 